\title{
Hand fracture epidemiology and etiology in children-time trends in Malmö, Sweden, during six decades
}

\author{
Vasileios Lempesis ${ }^{*}$ D, Björn E. Rosengren, Lennart Landin, Carl Johan Tiderius and Magnus K. Karlsson
}

\begin{abstract}
Background: The aim of this study was to describe hand fracture epidemiology/etiology in city children and describe time trend during six decades.

Patients and methods: A single hospital serves the entire city population of 271,271 (year 2005). Through the hospital medical and radiological archives, we collected epidemiology and etiology data concerning pediatric (age < 16years) hand fractures in city residents, treated during 2005-2006. We compared these data to previously collected data in in the same city during 12 evaluated periods from 1950/1955 to 1993-1994. We present periodspecific crude and age- and gender-adjusted fracture incidence rates and group differences as incidence rate ratios (RR) with 95\% confidence intervals (95\% Cl).

Results: In 2005-2006, we identified 414 hand fractures (303 in boys and 111 in girls), 247 phalangeal fractures (60\% of all hand fractures), 140 metacarpal/carpal fractures (except the scaphoid bone) (34\%), and 27 scaphoid fractures (6\%). The crude hand fracture rate in children was 448/100,000 person years (639/100,000 in boys and 247/100,000 in girls), with a 2.5 times higher age-adjusted incidence in boys than in girls. Compared to 1950/1955, the age and genderadjusted hand fracture incidence was twice as high in 2005-2006 and more than twice as high in 1976-1979. Compared to 1976-1979, we found no significant difference in the age and gender-adjusted hand fracture incidence in 2005-2006. In 2005-2006, sports injuries explained 42\%, fights 20\%, and traffic accidents 13\% of the hand fractures. In 1950/1955, sports injuries explained $27 \%$ of fractures, fights 10\%, and traffic accidents $21 \%$.
\end{abstract}

Conclusions: The incidence of hand fractures in children was more than twice as high in the end of the 1970s compared to the 1950s, where after no significant change could be found. Also, fracture etiology has changed. New studies are needed, to adequately allocate health care resources and identify new fracture prone activities suitable for preventive measures.

Level of evidence: III

Keywords: Boy, Girl, Fractures, Epidemiology, Time trends

\section{Background}

The hand is one of the most commonly injured anatomic regions, accounting for $29 \%$ of pediatric visits in emergency departments $[1,2]$. Around one fourth of those patients have a fracture [3, 4], with the hand being the second most fractured region, surpassed only by the distal forearm [5-9]. However, there are gender

\footnotetext{
*Correspondence: Vasileios.Lempesis@med.lu.se

Clinical and Molecular Osteoporosis Research Unit, Department of Clinical

Sciences and Orthopedics, Lund University, Skåne University Hospital, SE-205 02 Malmö, Sweden
}

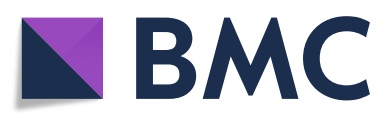

(c) The Author(s). 2019 Open Access This article is distributed under the terms of the Creative Commons Attribution 4.0 International License (http://creativecommons.org/licenses/by/4.0/), which permits unrestricted use, distribution, and reproduction in any medium, provided you give appropriate credit to the original author(s) and the source, provide a link to the Creative Commons license, and indicate if changes were made. The Creative Commons Public Domain Dedication waiver (http://creativecommons.org/publicdomain/zero/1.0/) applies to the data made available in this article, unless otherwise stated.

differences in hand fracture occurrence, as well as differences in age incidences, with boys having higher incidences than girls and girls having an earlier peak incidence than boys $[6,8]$. As time trends in fracture epidemiology have changed in boys and in girls during recent decades [3,6, 7, 9-18], there is a need for updated pediatric fracture epidemiology. This also accounts for etiology data, in order to identify new fracture prone activities in need of prevention and evaluate the effect of already existing fracture prevention strategies. 
The aim of this study is to describe hand fracture epidemiology/etiology in children in 2005-2006 and with use of previously published data from the same area $[6,9]$, evaluate time trends in age- and gender-standardized fracture incidences from 1950/1955 to 2005-2006.

\section{Patients and methods}

Our city is located in the southern part of the country with a population of 276,244 inhabitants $(46,429<16$ years of age) in year 2006 [19]. One hospital provides trauma care for the entire city and this hospital archives store all medical charts, referrals, radiographs, and reports since a century [20], making it possible to re-evaluate former patients. Radiographs were until the year 2001, sorted according to anatomical region, year of injury, and diagnosis. Researchers have utilized this archive to describe pediatric fracture epidemiology in city residents $<16$ years during the years 1950, 1955, 1960, 1965, 1970, 1975-1979 [6], and 1993-1994 [9]. These studies have reported changes in crude hand fracture incidences [6] and crude overall fracture incidences [9], however, without adjusting for changes in demography within the population at risk.

In 2001, the radiographic archive was replaced by a digital archive. This system includes radiographs performed within the healthcare system in the entire southern part of the country, including the Malmo city hospital. The radiographs are now classified according to each specific patient (through a unique 10-digit personal identity number), diagnosis, and anatomical location. Pediatric fracture cases 2005-2006 were therefore identified through this classification in the digital in- and outpatient diagnosis records at the Emergency Department, Departments of Orthopedics, Hand Surgery, and Otorhinolaryngology. We included records that fulfilled the following criteria: (i) ICD-10 fracture diagnosis: S02.3-S02.4, S02.6-S02.9, S12.0-S12.2, S12.7, S22.0, S32.0-S32.8, S42.0-S42.9, S52.0-S52.9, S62.0-S62.8, S72.0-S72.9, S82.0-S82.9, and S92.0-S92.9; (ii) age $<16$ years at the time of the incident fracture; and (iii) city resident at the time of the injury.

We identified 4459 visits with a fracture diagnosis during 2005-2006 and 1548 with a hand fracture diagnosis (ICD-10 code S62.0-S62.8). To verify hand fractures, we reviewed medical charts, referrals, radiographic reports, and radiographs of all fracture visits. This enabled us to exclude all follow-up visits after an index fracture visit, thus avoiding double counting of a fracture. Patients who received emergency treatment in other hospitals are in our country, as standard, referred to the home hospital for follow-up evaluation. Such fractures were then captured in the hospital archives.

We collected pediatric fracture data from 2005 to 2006, following the same protocol as in the previous studies $[6,9]$. Thus, we included data on patient age and gender, number of fractures, date of the fracture, fractured region/regions, and fracture etiology. During the years 2005-2006, we could determine the etiology in $70 \%$ of the cases compared to $40 \%$ during the years 1950/1955.

Multiple phalangeal fractures, multiple metacarpal fractures, and combinations of carpal and metacarpal fractures were registered as separate fractures. This was done to provide detailed information about the anatomical distribution of hand fractures and, by this, facilitate comparisons with other single center reports that register multiple metacarpal and phalangeal fractures separately $[4,12,13,17,18,21-26]$. To compare the current data to the previously collected data from the same city, we recorded fracture events according to the previous classification protocol $[6,9]$, that is with three different groups: (i) fractures of the phalanges of the digits, (ii) fractures of the metacarpals or carpal bones, and (iii) fractures of the scaphoid. Multiple fractures in phalangeal, metacarpal, and carpal bones sustained at the same event were in this classification regarded as a single fracture, while multiple fractures on the same patient, bilateral fractures, and new fractures of an already fractured bone were classified as independent fractures $[6,9]$. As in previous studies $[6,9]$, we did not include patients with traumatic amputations.

To validate the new fracture ascertainment system, one author (VL) performed a search in the digital radiological archive for all pediatric skeletal radiographs, independent on the reason for the referral, at the radiology department of the hospital from January 1, 2005, to February 28, 2005. The author reviewed all radiographs and then identified 103 pediatric fractures sustained in city residents. The same researcher then conducted a second search by the use of the same search criteria in the digital in- and outpatient diagnosis record archive. This second search also identified 103 fractures. One hundred fractures were identified by both methods; each method alone identified 103 fractures, while the two methods combined identified 106 fractures. Each method thereby missed three fractures, a miscalculation rate of $3 \%$.

For statistical calculations, we organized hand fracture data in six periods $(1950 / 1955,1960 / 1965,1970 / 1975$, 1976-1979, 1993-1994, and 2005-2006). Data on the population at risk (i.e., city residents $<16$ years) during each period was retrieved through official records [19]. Age- and gender-standardized rates were calculated through direct standardization, with the average pediatric city population (in 1-year classes) during the study period as reference. Results are presented as number of fractures, mean fracture incidences per 100,000 person years, and as proportions (\%) of all fractures. To estimate differences in rates between evaluated periods, we calculated rate ratios (RR) by use of the chi-square distribution, including 95\% confidence intervals (95\% 
CI) to describe uncertainty. We considered $p<0.05$ as a statistically significant difference.

\section{Results}

\section{All hand fractures 2005-2006}

The distribution of hand fractures $(n=437)$ in city residents aged $<16$ during 2005-2006 is reported by anatomical location in Fig. 1, by sex in Additional file 1: Figure S1, and by side in Additional file 2: Figure S2.

Fractures 2005-2006, classified as in the previous reports from the same city $[6,9]$ )

By this classification system (multiple fractures in phalangeal, metacarpal, and carpal bones at the same event classified as a single fracture), we found 414 hand fractures (303 in 294 boys and 111 in 108 girls). This corresponds to $24 \%$ ( $27 \%$ in boys and $19 \%$ in girls) of the total number of 1692 fractures (1119 fractures in 1062 boys and 573 in 553 girls) (Table 1). The crude incidence rate of hand fractures was 448/100,000 person years (639 in boys and 247 in girls), with boys having 2.5 times higher age-adjusted incidence than girls (RR 2.5; 95\% CI 1.8 to 3.5 ) (Table 1).

The numbers and the crude and age-adjusted incidence rates of phalangeal, carpal/metacarpal, and of scaphoid fractures are presented in Additional file 3: Table S1, Additional file 4: Table S2, and Additional file 5: Table S3. Boys compared to girls had a 70\% higher ageadjusted incidence of phalangeal fractures (RR 1.7; 95\%

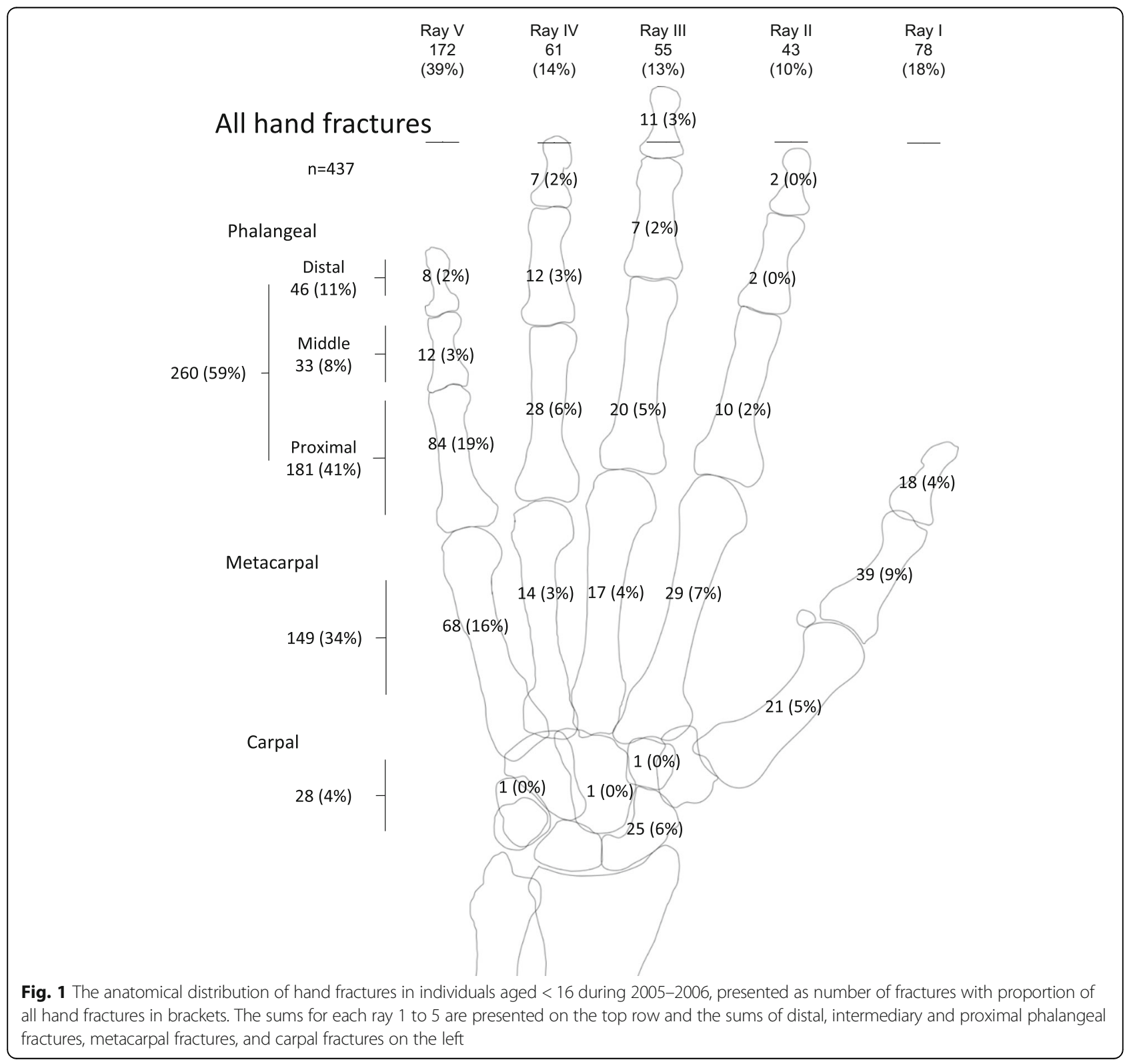


Table 1 Number of hand fractures, crude, and age-adjusted incidence rates (/100,000 person years) in boys, girls, and all children aged < 16 during six separate periods from 1950/1955 to 2005-2006

\begin{tabular}{|c|c|c|c|c|c|c|c|}
\hline \multicolumn{8}{|c|}{ Hand fractures in children aged $<16$ in our city year 1950/1955 to 2005-2006 } \\
\hline & & 1950/1955 & 1960/1965 & 1970/1975 & $1976-1979$ & 1993-1994 & $2005-2006$ \\
\hline \multirow[t]{3}{*}{ Number of fractures } & All children & 191 & 298 & 411 & 921 & 369 & 414 \\
\hline & Boys & 131 & 198 & 269 & 616 & 250 & 303 \\
\hline & Girls & 60 & 100 & 142 & 305 & 119 & 111 \\
\hline \multirow[t]{3}{*}{ Crude incidence } & All children & 205 & 288 & 429 & 573 & 449 & 448 \\
\hline & Boys & 275 & 373 & 549 & 747 & 591 & 639 \\
\hline & Girls & 131 & 198 & 304 & 389 & 298 & 247 \\
\hline \multirow[t]{3}{*}{ Age-adjusted incidence } & All children & 220 & 281 & 421 & 528 & 492 & 439 \\
\hline & Boys & 297 & 363 & 537 & 686 & 653 & 619 \\
\hline & Girls & 139 & 195 & 299 & 362 & 323 & 249 \\
\hline
\end{tabular}

CI 1.3 to 2.2), eight times higher incidence of carpal/ metacarpal fractures (RR 7.9; 95\% CI 4.6 to 14.4), and 2.3 times higher incidence of scaphoid fractures (RR 2.3; 95\% CI 0.6 to 36.2 ).

\section{Peak incidence rate in boys and girls in 2005-2006}

Boys reached the highest age-specific incidence rate for hand fractures (any), for phalangeal fractures, and for scaphoid fractures at age 12-13 years and for metacarpal/carpal fractures at age 14-15 years (Fig. 2). Girls reached the highest age-specific incidence rate for hand fractures (any) and scaphoid fractures at age 14-15 years and for metacarpal/carpal and phalangeal fractures at age $12-13$ years (Fig 2).

\section{Side preponderance 2005-2006}

We found no side preponderance for hand fractures (any) (right to left rate ratio RR 1.2; 95\% CI 0.99 to 1.5 ) or in phalangeal fractures (RR 1.0; $95 \%$ CI 0.7 to 1.2 ) while metacarpal/carpal fractures were more common in the right hand (RR 2.1; 95\% CI 1.5 to 3.0). Right to left rate ratios for any hand fracture, for phalangeal fractures, and for metacarpal/carpal fractures in all children, in boys, and in girls are presented in Additional file 6: Table S4.
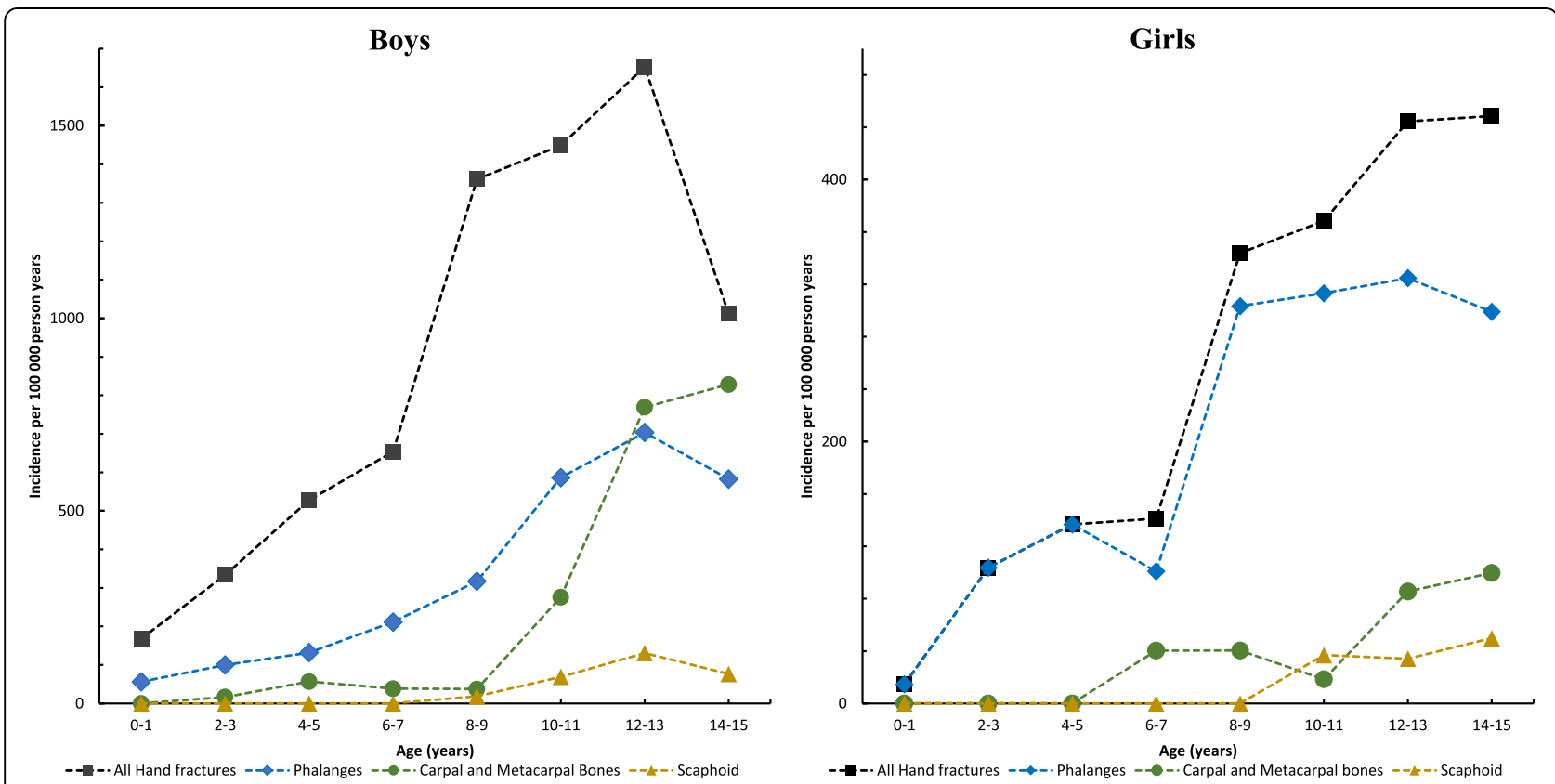

Fig. 2 Age-specific incidence rates of all types of hand fractures, fractures of the phalanges, fractures of the metacarpals/carpal bones, and fractures of the scaphoid bone in boys and girls during 2005-2006, presented as number of fractures /100,000 person years 
Time trends in incidence rates from 1950/1955 to 2005-2006 The lowest age-adjusted incidence rate of pediatric hand fractures was found in 1950/1955 and the highest in 1976-1979 (Table 1). The age- and gender-standardized fracture rate in 1976-1979 was more than twice as high as 1950/1955 (RR 2.4; 95\% CI 1.9 to 3.1) (Tables 1 and $2)$. The age- and gender-standardized fracture rate in 2005-2006 was 20\% lower than 1976/1979 (RR 0.8; 95\% CI 0.7 to 1.01 ) but double compared to $1950 / 1955$ (RR 2.0; 95\% CI 1.6 to 2.6) (Tables 1 and 2). Gender-specific time trend data are presented in Fig. 3 and Table 2.

Crude- and age-adjusted incidence rates of phalangeal fractures and fractures of the metacarpal/carpal bones between the different periods are reported in Additional file 7: Table S5 and Additional file 8: Table S6. Time trends were not evaluated for scaphoid fractures due to the low number of fractures.

\section{Time trends from 1950/1955 to 2005-2006 in peak incidence rates in boys and girls}

Boys reached in 2005-2006 the highest age-specific hand fracture incidence at the age of 12-13 years, while the highest incidence in 1950/1955 and 1976-1979 was found at age 14-15 (Fig. 4). Girls reached in 2005-2006 the highest age-specific hand fracture incidence at age 14-15 while the highest incidence in 1950/1955 and 1976-1979 was found at age 12-13 (Fig. 4).

\section{Etiology of hand fractures in 2005-2006 and time trends from 1950/1955 to 2005-2006}

Hand fractures etiology data are presented in Table 3, for phalangeal and metacarpal/carpal fractures in Additional file 9: Table S7 and Additional file 10: Table S8. The most common etiologies for hand fractures 20052006 were sports trauma, fights, and traffic accidents. The most common etiologies for hand fractures 1950/1955 were sports injuries, traffic accidents, and accidents at school. Traffic accidents and home accidents accounted for the lowest proportion of hand fractures during the evaluated years 2005-2006 while the proportion of fights as etiology was highest 2005-2006.

\section{Discussion}

One fourth of all pediatric fractures 2005-2006 affected the hand. Hand fractures (any) were 2.5 times and metacarpal/carpal fractures 8 times more common in boys than in girls. Hand fracture incidences increased with age in both genders until puberty. Girls reached peak incidence rates 2 years ahead of boys, that is, our data support the notion that hand fracture incidence rate is higher in boys than in girls and that there is a higher incidence with increasing age until a peak around puberty $[4,6,9,12,13,17,23,25,27,28]$.

The pediatric crude hand fracture incidence in 20052006 (448/100,000 person years) was in our city higher than 2005 in Helsinki Finland (344/100,000) [8], higher than 2006-2007 in the northern part of our country (389/100,000) [29], and 18 times higher than 1996-2001 in British Columbia (Canada) (24/100,000 person years) [24]. The discrepancies could be the result of different study methodology. For example, in our study, only one hospital serves the entire region, while several hospitals served the population at risk in the Canadian study. However, there could also be actual differences in fracture incidence rates, supported by the UK data, reporting that fracture incidences in county regions varied compared to London with a incidence rate ratio ranging from 1.0 to 1.7 [5]. Since ethnicity influences the fracture risk $[15,30,31]$, a different mixture of ethnicity in different regions and countries could also explain regional fracture incidence differences.

The age-adjusted hand fracture incidence rate was in our city more than double 1976-1979 compared to 1950/1955 and 20\% higher than 2005-2006 (not reaching statistical significance). This suggests that there could have been a trend break in pediatric fracture incidence at the

Table 2 Differences in crude and age-adjusted hand fracture incidence in children, in boys and in girls aged <16, from 1950/1955 to 1976-1979 (previously only reported as crude changes [6]) and to 2005-2006 (changes from the first to the most recent evaluated period), from 1976/1979 to 1993/1994 (previously only reported as crude changes [9]) and to 2005-2006 (changes from the period with the highest reported fracture incidence [6] to the most recent evaluated period), and from 1993 to 1994 to $2005-2006$ (changes from the last reported fracture incidence [9] to the most recent evaluated period)

\begin{tabular}{|c|c|c|c|c|c|c|}
\hline \multirow{2}{*}{$\begin{array}{l}\text { Denominator } \\
\text { Nominator }\end{array}$} & & \multicolumn{2}{|l|}{$1950 / 1955$} & \multicolumn{2}{|l|}{ 1976-1979 } & \multirow{2}{*}{$\begin{array}{l}1993-1994 \\
2005-2006\end{array}$} \\
\hline & & 1976-1979 & 2005-2006 & 1993-1994 & $2005-2006$ & \\
\hline \multirow[t]{3}{*}{ Unadjusted } & All Children & 2.8 (2.4 to 3.3$)$ & 2.2 (1.8 to 2.6$)$ & $0.8(0.7$ to 0.9$)$ & $0.8(0.7$ to 0.9$)$ & $1.0(0.9$ to 1.1$)$ \\
\hline & Boys & 2.3 (1.9 to 2.9$)$ & 2.3 (1.9 to 2.9 ) & $0.8(0.7$ to 0.9$)$ & 0.9 (0.7 to 0.98$)$ & 1.1 (0.9 to 1.3 ) \\
\hline & Girls & $3(2.2$ to 3.9$)$ & 1.9 (1.4 to 2.6$)$ & 0.8 (0.6 to 0.9 ) & 0.6 (0.5 to 0.8$)$ & 0.8 (0.6 to 1.1$)$ \\
\hline \multirow[t]{3}{*}{ Age-adjusted } & All children & 2.4 (1.9 to 3.1$)$ & 2 (1.6 to 2.6) & 0.9 (0.8 to 1.1$)$ & $0.8(0.7$ to 1.01$)$ & $0.9(0.7$ to 1.1$)$ \\
\hline & Boys & 2.3 (1.7 to 3.1$)$ & 2.1 (1.5 to 2.8 ) & 1.0 (0.8 to 1.2 ) & 0.9 (0.7 to 1.1$)$ & 0.9 (0.7 to 1.2$)$ \\
\hline & Girls & $2.6(1.7$ to 4.1$)$ & 1.8 (1.1 to 2.9$)$ & 0.9 (0.6 to 1.2$)$ & 0.7 (0.5 to 0.98$)$ & 0.8 (0.5 to 1.1$)$ \\
\hline
\end{tabular}

Comparisons are presented as rate ratios with $95 \%$ confidence intervals $(95 \% \mathrm{Cl})$ within brackets. Statistically significant changes are in italics 

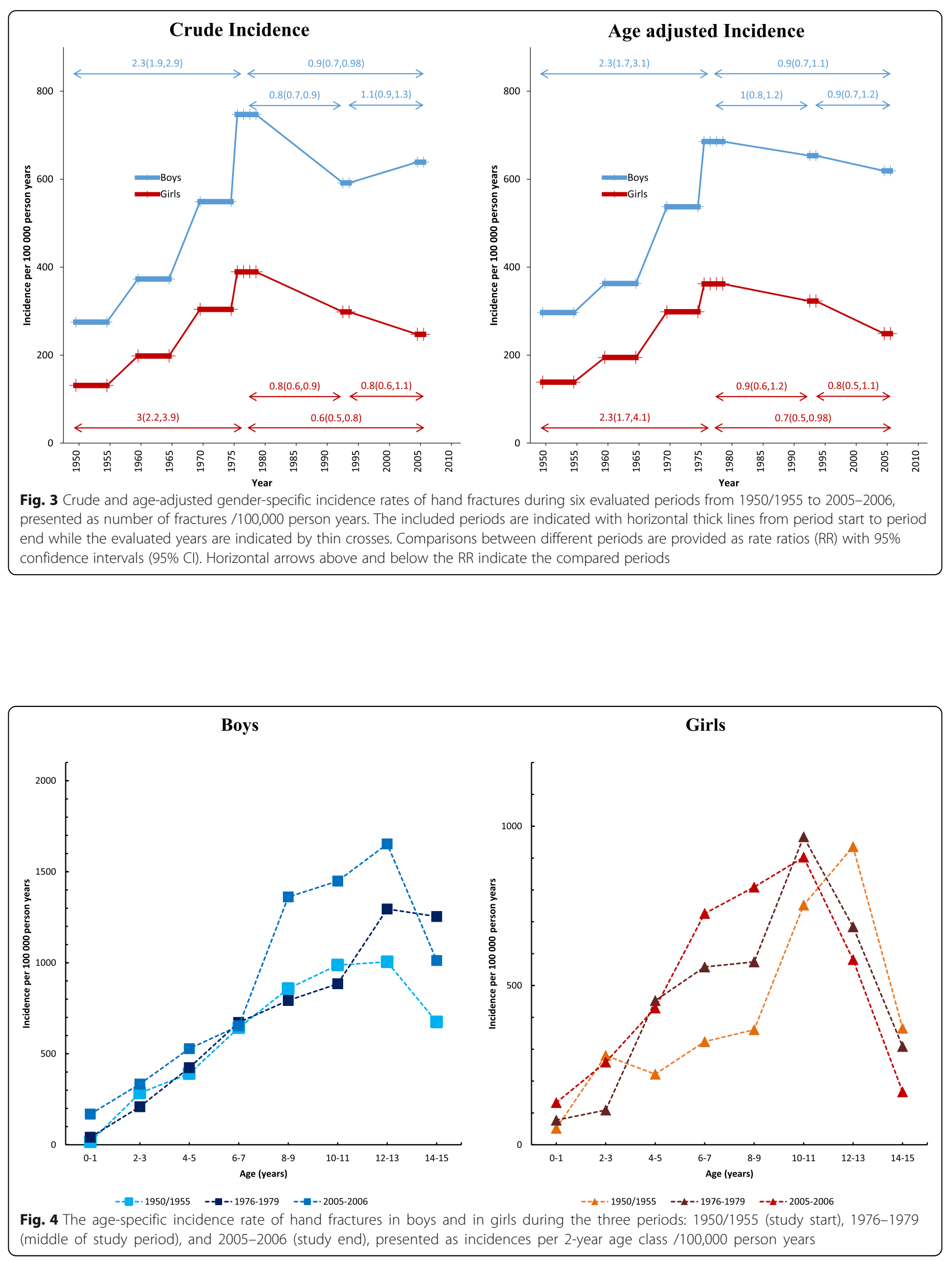
Table 3 Etiology of hand fractures in individuals aged < 16 during six separate periods from 1950/1955 to 2005 -2006 (for the last period also separate in boys and girls). Etiology data was missing in 58\% of cases in 1950/1955, 49\% in 1960/1965, 41\% in 1970/ 1975, 42\% in 1976-1979, 28\% in 1993-1994, and 30\% in 2005/2006. Data are presented as the proportions (\%) of different etiologies among the cases where etiology (fracture related activity) could be determined

\begin{tabular}{|c|c|c|c|c|c|c|c|c|}
\hline \multirow[t]{2}{*}{ Environmental factors } & \multicolumn{5}{|l|}{ All children } & \multirow{2}{*}{$\begin{array}{l}\text { All children } \\
2005-2006 \\
(\%)\end{array}$} & \multirow{2}{*}{$\begin{array}{l}\text { Boys } \\
2005-2006 \\
(\%)\end{array}$} & \multirow{2}{*}{$\begin{array}{l}\text { Girls } \\
2005-2006 \\
(\%)\end{array}$} \\
\hline & $\begin{array}{l}\text { 1950/1955 } \\
(\%)\end{array}$ & $\begin{array}{l}\text { 1960/1965 } \\
(\%)\end{array}$ & $\begin{array}{l}\text { 1970/1975 } \\
\text { (\%) }\end{array}$ & $\begin{array}{l}1976-1979 \\
(\%)\end{array}$ & $\begin{array}{l}1993-1994 \\
(\%)\end{array}$ & & & \\
\hline Home accidents & 9.9 & 5.9 & 8.7 & 3.2 & 6.8 & 1.0 & 0.5 & 2.7 \\
\hline Day nursery accidents & 0 & 0 & 0.4 & 0.2 & 1.5 & 1.4 & 1.9 & 0 \\
\hline School accidents & 14.8 & 9.8 & 7.0 & 6.2 & 4.5 & 10.4 & 10.7 & 9.6 \\
\hline Work accidents & 3.7 & 0 & 0 & 0 & 1.5 & 0 & 0 & 0 \\
\hline Traffic accidents & 21.0 & 16.3 & 14.9 & 14.0 & 18.8 & 13.2 & 13.5 & 12.3 \\
\hline Bicycle accidents & 18.5 & 7.8 & 9.1 & 8.6 & 13.9 & 12.2 & 12.1 & 12.3 \\
\hline Pedestrian hit by vehicle & 1.2 & 4.6 & 0.4 & 0.7 & 0 & 0 & 0 & 0 \\
\hline Moped, motorcycle & 0 & 2.0 & 2.1 & 1.9 & 1.9 & 1.0 & 1.4 & 0 \\
\hline Car passenger & 1.2 & 0.7 & 2.9 & 2.6 & 0.8 & 0 & 0 & 0 \\
\hline Other & 0 & 1.3 & 0.4 & 0.2 & 2.3 & 0 & 0 & 0 \\
\hline Playing accidents & 12.3 & 21.6 & 14.0 & 13.6 & 14.7 & 11.1 & 9.3 & 16.4 \\
\hline Playground & 1.2 & 2.0 & 1.7 & 1.1 & 2.3 & 2.1 & 1.4 & 4.1 \\
\hline In-lines, skateboard & 0 & 0 & 0 & 1.9 & 1.9 & 2.4 & 1.9 & 4.1 \\
\hline Sledge, other "snow" & 0 & 0 & 0.8 & 1.7 & 1.1 & 1.0 & 1.4 & 0 \\
\hline Other play accidents & 11.1 & 19.6 & 11.6 & 9.0 & 9.4 & 5.6 & 4.7 & 8.2 \\
\hline Sport accidents & 27.2 & 34.0 & 40.1 & 46.7 & 39.8 & 42.4 & 39.1 & 52.1 \\
\hline Ball-game & 19.8 & 26.8 & 30.2 & 33.6 & 26.3 & 29.9 & 28.4 & 34.2 \\
\hline Ice-hockey, skating & 3.7 & 3.9 & 5.0 & 3.6 & 2.6 & 2.8 & 3.3 & 1.4 \\
\hline Gymnastics and athletics & 0 & 0 & 0 & 1.1 & 2.6 & 0 & 0 & 0 \\
\hline Horse accidents & 3.7 & 0.7 & 2.5 & 2.8 & 2.6 & 1.7 & 0 & 6.8 \\
\hline Wrestling, boxing, etc. & 0 & 0.7 & 0.4 & 1.9 & 3.4 & 3.5 & 4.2 & 1.4 \\
\hline Skiing & 0 & 0.7 & 2.1 & 3.4 & 1.5 & 2.1 & 1.9 & 2.7 \\
\hline Other & 0 & 1.3 & 0 & 0.4 & 0.8 & 2.4 & 1.4 & 5.5 \\
\hline Fights & 9.9 & 12.4 & 13.2 & 13.5 & 11.3 & 20.1 & 24.7 & 6.8 \\
\hline Other & 1.2 & 0 & 1.7 & 2.6 & 1.1 & 0.3 & 0.5 & 0 \\
\hline
\end{tabular}

end of the 1970s. Some of the time trends could be attributed to changes in demographics, since after adjustment for age, time trend changes were no longer statistically significant in boys. Finnish data however support a time trend change in pediatric fracture rates, reporting a higher pediatric hand fracture incidence in 2005 than in 1967 and around 50\% lower incidence in 2005 than in 1983 [8]. However, in contrast to our study, the Finnish study only compared absolute incidences, but without conducting statistical comparisons.

Etiology data indicate that safety requirements for toy manufacturing, playground construction, protective sports gear, and accident prevention in traffic and home environment have positively influenced time trends in pediatric fracture incidence $[32,33]$. Time trends in life style, such as more violent fights and less physical activity among children, may also influence time trends.
Swedish children have reduced their everyday physical activity during recent decades, instead spending more time in front of monitors [34], and low levels of physical activity is a risk factor for fractures $[35,36]$. The proportion of children with foreign background in our city was, in 2005-2006, also higher than during previous decades $[37,38]$, another difference that could have influenced time trends [15, 30, 31].

Study strengths include the epidemiology and etiology data from a well-defined cohort during six decades. Inclusion of only objectively verified fractures, without double counting due to multiple visits, is another strength. Weaknesses include the modification of the data collection method, due to the change in archiving method in the year 2001. However, our validation found a $3 \%$ miscalculation rate, the same as with the previous method $[6,9]$. Another weakness is the risk of missing 
fractures exclusively treated outside the catchment area. People may be more mobile today than previously, sustaining more fractures that receive treatment at other hospitals. Since the standard treatment in Sweden still is to refer these cases to follow-up visits at the home hospitals, there is a minor risk to miss these fractures. Another confounder could be that individuals, decades ago, were less prone to seek medical advice and that doctors at that time were more hesitant to send patients to X-ray exams than today, thereby missing actual fractures. If this actually was the case is today impossible to clarify. A larger sample size would have been advantageous, especially for subgroup analyses making time trend analyses of rarer fracture types possible. Finally, the larger proportion of missing fracture etiology historically than at the last follow-up is another limitation and the reason to why we refrained from statistical analysis of time trend changes in etiology.

\section{Conclusions}

In conclusion, the incidence rate of hand fractures is higher in older than younger children, phalangeal fractures are more common than metacarpal fractures, and hand fractures are 2.5 times more common in boys than girls. The age-adjusted incidence rate of hand fractures in children was more than doubled in 1976-1979 compared to that in 1950/1955, with obvious differences also in fracture etiology. There may have been a trend break in 1976-1979, since we found a $20 \%$ lower fracture incidence in 2005-2006 than in 1976-1979, a time trend change not reaching statistical significance but inferring the need to continue to follow pediatric fracture incidences.

\section{Additional files}

Additional file 1: Figure S1. The anatomical distribution of hand fractures in boys and girls aged $<16$ during 2005-2006, presented as number of fractures with proportion of all hand fractures in the respective gender in brackets. The sums for each ray 1 to 5 are presented on the top row and the sums of distal, intermediary and proximal phalangeal fractures, metacarpal fractures and carpal fractures on the left. (PPTX $85 \mathrm{~kb}$ )

Additional file 2: Figure S2. The anatomical distribution of hand fractures in the left and the right hand in individuals aged $<16$ during 2005-2006, presented as number of fractures with proportion of all hand fractures in the respective hand in brackets. The sums for each ray 1 to 5 are presented on the top row and the sums of distal, intermediary and proximal phalangeal fractures, metacarpal fractures and carpal fractures on the left and right side, respectively. (PPTX $85 \mathrm{~kb}$ )

Additional file 3: Table S1. Number of phalangeal fractures with crude and age-adjusted incidence rates (/100,000 person years) in boys, in girls and in all children aged $<16$ during six separate periods from 1950/1955 to 2005-2006. (DOCX $13 \mathrm{~kb}$ )

Additional file 4: Table S2. Number of metacarpal/carpal bones fractures (except the scaphoid bone) with crude and age-adjusted incidences (/100,000 person years) in boys, in girls and in all children aged $<16$ during six separate periods from 1950/1955 to 2005-2006. (DOCX 13 kb)

Additional file 5: Table S3. Number of scaphoid bone fractures with crude and age-adjusted incidences (/100,000 person years) in boys, in girls and in all children aged < 16 during six separate periods from 1950/1955 to 2005-2006. (DOCX 13 kb)

Additional file 6: Table S4. Right to left distribution of any hand fracture, for fractures of the phalanges and the carpal/metacarpal bones (excluding the scaphoid) in all children, in boys and in girls for the period 2005-2006. Comparisons are presented as Rate Ratios (RR) with 95\% Confidence Intervals (95\% Cl) within brackets. Statistically significant changes are bolded. The distribution of scaphoid fractures was not examined due to a low number of fractures. (DOCX $14 \mathrm{~kb}$ )

Additional file 7: Table S5. Differences in crude and age-adjusted incidence of fractures of the phalanges of the hand in children, in boys and in girls aged < 16, from 1950/1955 to 1976-1979 (previously only reported as crude changes [6]) and to 2005-2006 (changes from the first to the most recent evaluated period), from 1976/1979 to 1993/1994 (previously only reported as crude changes [9]) and to 2005-2006 (changes from the period with the highest reported fracture incidence [6] to the most recent evaluated period) and from 1993 to 1994 to 20052006 (changes from the last reported fracture incidence [9] to the most recent evaluated period). Comparisons are presented as Rate Ratios with $95 \%$ Confidence Intervals (95\% Cl) within brackets. Statistically significant changes are bolded. (DOCX $16 \mathrm{~kb}$ )

Additional file 8: Table S6. Differences in crude and age-adjusted incidence of fractures of the metacarpals/carpal bones (except the scaphoid bone) in children, in boys and in girls aged < 16. from 1950/1955 to 1976-1979 (previously only reported as crude changes [6]) and to 20052006 (changes from the first to the most recent evaluated period), from $1976 / 1979$ to $1993 / 1994$ (previously only reported as crude changes [9]) and to 2005-2006 (changes from the period with the highest reported fracture incidence [6] to the most recent evaluated period) and from 1993 to 1994 to 2005-2006 (changes from the last reported fracture incidence [9] to the most recent evaluated period). Comparisons are presented as Rate Ratios with 95\% Confidence Intervals (95\% Cl) within brackets. Statistically significant changes are bolded. (DOCX 13 kb)

Additional file 9: Table S7. Etiology of phalangeal fractures in individuals aged < 16 during six separate periods from 1950/1955 to 2005-2006 (for the last period also separate in boys and girls). Etiology data was missing in $60 \%$ of cases in 1950/1955, 55\% in 1960/1965, 44\% in 1970/1975, 44\% in 1976-1979, 31\% in 1993-1994 and 31\% in 2005/2006. Data are presented as the proportions (\%) of different etiologies among the cases where etiology (fracture related activity) could be determined. (DOCX $15 \mathrm{~kb}$ )

Additional file 10: Table S8. Etiology of metacarpal/carpal fractures (except the scaphoid bone) in individuals aged $<16$ during six separate periods from 1950/1955 to 2005-2006 (for the last period also separate in boys and girls) Etiology data was missing in 56\% of cases in 1950/1955, $35 \%$ in $1960 / 1965,32 \%$ in $1970 / 1975,37 \%$ in $1976-1979,22 \%$ in $1993-1994$ and $33 \%$ in 2005/2006. Data are presented as the proportions (\%) of different etiologies among the cases where etiology (fracture related activity) could be determined. (DOCX $15 \mathrm{~kb}$ )

\section{Acknowledgements}

We would like to express our gratitude to Hans Eric Rosberg, Department of Hand Surgery, Skåne University Hospital, for his help with data collection.

\section{Authors' contributions}

All the authors have been actively involved in the planning and enactment of the study and have also assisted with the preparation of the submitted article. All authors read and approved the final manuscript.

\section{Funding}

Financial support was provided by ALF, Herman Järnhardts Foundation, Greta and Johan Kocks Foundation, Region Skåne FoU, and the Faculty of Medicine at Lund University. The funding sources were not involved in the design, conduct, or interpretation of the study or in the writing of the submitted work.

\section{Availability of data and materials}

The datasets used and/or analyzed during the current study are available from the corresponding author on reasonable request. 


\section{Ethics approval and consent to participate}

The study was approved by the ethical committee, Lund University (reference number 2010/191), and was conducted in accordance with the Declaration of Helsinki. In accordance with the requirements of the ethical committee, the public was informed of the study through the local newspaper and participants had the choice to opt out.

\section{Consent for publication}

Not applicable

\section{Competing interests}

The authors declare that they have no competing interests.

Received: 24 May 2019 Accepted: 25 June 2019

Published online: 12 July 2019

\section{References}

1. Danseco ER, Miller TR, Spicer RS. Incidence and costs of 1987-1994 childhood injuries: demographic breakdowns. Pediatrics. 2000;105(2):E27 PubMed PMID: 10654987.

2. Scheidt PC, Harel $Y$, Trumble AC, Jones DH, Overpeck MD, Bijur PE. The epidemiology of nonfatal injuries among US children and youth. Am J Public Health. 1995;85(7):932-8 PubMed PMID: 7604916. Pubmed Central PMCID: 1615546

3. Angermann P, Lohmann M. Injuries to the hand and wrist. A study of 50,272 injuries. J Hand Surg Br. 1993;18(5):642-4 PubMed PMID: 8294834.

4. van Onselen EB, Karim RB, Hage JJ, Ritt MJ. Prevalence and distribution of hand fractures. J Hand Surg Br. 2003;28(5):491-5 PubMed PMID: 12954264.

5. Cooper C, Dennison EM, Leufkens HG, Bishop N, van Staa TP. Epidemiology of childhood fractures in Britain: a study using the general practice research database. J Bone Miner Res. 2004;19(12):1976-81 PubMed PMID: 15537440.

6. Landin LA. Fracture patterns in children. Analysis of 8,682 fractures with special reference to incidence, etiology and secular changes in a Swedish urban population 1950-1979. Acta Orthop Scand Suppl. 1983:202:1-109 PubMed PMID: 6574687.

7. Lempesis V, Rosengren BE, Nilsson JA, Landin L, Tiderius CJ, Karlsson MK Time trends in pediatric fracture incidence in Sweden during the period 1950-2006. Acta Orthop. 2017;88(4):440-5 PubMed PMID: 28562146. Pubmed Central PMCID: 5499338.

8. Mayranpaa MK, Makitie O, Kallio PE. Decreasing incidence and changing pattern of childhood fractures: a population-based study. J Bone Miner Res. 2010;25(12):2752-9 PubMed PMID: 20564246.

9. Tiderius CJ, Landin L, Duppe H. Decreasing incidence of fractures in children: an epidemiological analysis of 1,673 fractures in Malmo, Sweden, 1993-1994. Acta Orthop Scand. 1999:70(6):622-6 PubMed PMID: 10665730

10. Buttazzoni C, Rosengren BE, Karlsson C, Dencker M, Nilsson JA, Karlsson MK. A pediatric bone mass scan has poor ability to predict peak bone mass: an 11-year prospective study in 121 children. Calcif Tissue Int. 2015;96(5):37988 PubMed PMID: 25716719

11. Naranje SM, Erali RA, Warner WC Jr, Sawyer JR, Kelly DM. Epidemiology of pediatric fractures presenting to emergency departments in the United States. J Pediatr Orthop. 2016:36(4):e45-8 PubMed PMID: 26177059.

12. Fontanesi $L$, Bertolini F, Scotti E, Schiavo G, Colombo M, Trevisi $P$, et al. Next generation semiconductor based-sequencing of a nutrigenetics target gene (GPR120) and association with growth rate in Italian Large White pigs. Anim Biotechnol. 2015;26(2):92-7 PubMed PMID: 25380460.

13. Stanton JS, Dias JJ, Burke FD. Fractures of the tubular bones of the hand. J Hand Surg Eur Vol. 2007:32(6):626-36 PubMed PMID: 17993422

14. Rosberg HE, Dahlin LB. Epidemiology of hand injuries in a middle-sized city in southern Sweden: a retrospective comparison of 1989 and 1997. Scand J Plast Reconstr Surg Hand Surg. 2004;38(6):347-55 PubMed PMID: 15841802.

15. Chung KC, Spilson SV. The frequency and epidemiology of hand and forearm fractures in the United States. J Hand Surg Am. 2001;26(5):908-15 PubMed PMID: 11561245

16. Turner K 3rd, Ozaki M, Hayes D Jr, Harahsheh A, Moltz K, Chintala K, et al. Index of suspicion. Pediatr Rev. 2006;27(6):231-7 PubMed PMID: 16740807.

17. Worlock PH, Stower MJ. The incidence and pattern of hand fractures in children. J Hand Surg Br. 1986;11(2):198-200 PubMed PMID: 3734557.

18. Barton NJ. Fractures of the phalanges of the hand in children. Hand. 1979; 11(2):134-43 PubMed PMID: 488788.
19. Statistics Sweden. Child population in the city of Malmö in one year classes, December 31st 2005/2006: Statistics Sweden; 2007. Available from: http:// www.statistikdatabasen.scb.se/sq/1052. Accessed 19 May 2019.

20. Herbertsson P, Hasserius R, Josefsson PO, Besjakov J, Nyquist F, Nordqvist A et al. Mason type IV fractures of the elbow: a 14- to 46-year follow-up study. J Bone Joint Surg Br. 2009;91(11):1499-504 PubMed PMID: 19880897.

21. Emery AE, Clack ER, Simon S, Taylor JL. Detection of carriers of benign Xlinked muscular dystrophy. Br Med J. 1967;4(5578):522-3 PubMed PMID: 6065987. Pubmed Central PMCID: 1749119.

22. Liu EH, Alqahtani S, Alsaaran RN, Ho ES, Zuker RM, Borschel GH. A prospective study of pediatric hand fractures and review of the literature. Pediatr Emerg Care. 2014;30(5):299-304 PubMed PMID: 24759492.

23. Vadivelu R, Dias JJ, Burke FD, Stanton J. Hand injuries in children: a prospective study. J Pediatr Orthop. 2006;26(1):29-35 PubMed PMID: 16439897.

24. Mahabir RC, Kazemi AR, Cannon WG, Courtemanche DJ. Pediatric hand fractures: a review. Pediatr Emerg Care. 2001;17(3):153-6 PubMed PMID: 11437136

25. De Jonge JJ, Kingma J, van der Lei B, Klasen HJ. Phalangeal fractures of the hand. An analysis of gender and age-related incidence and aetiology. J Hand Surg Br. 1994:19(2):168-70 PubMed PMID: 8014541.

26. Packer GJ, Shaheen MA. Patterns of hand fractures and dislocations in a district general hospital. J Hand Surg Br. 1993:18(4):511-4 PubMed PMID: 8409670.

27. Feehan LM, Sheps SB. Incidence and demographics of hand fractures in British Columbia, Canada: a population-based study. J Hand Surg Am. 2006; 31(7):1068-74 PubMed PMID: 16945705.

28. Wieslander JB, Wendeberg B, Linge G, Buttazzoni G, Buttazzoni AM. Tissue expansion: a method to preserve bone length and joints following traumatic amputations of the leg--a follow-up of five legs amputated at different levels. Plast Reconstr Surg. 1996;97(5):1065-71 PubMed PMID: 8618975.

29. Hedstrom EM, Svensson O, Bergstrom U, Michno P. Epidemiology of fractures in children and adolescents. Acta Orthop. 2010;81(1):148-53 PubMed PMID: 20175744. Pubmed Central PMCID: 2856220.

30. Moon RJ, Harvey NC, Curtis EM, de Vries F, van Staa T, Cooper C. Ethnic and geographic variations in the epidemiology of childhood fractures in the United Kingdom. Bone. 2016;85:9-14 PubMed PMID: 26802259. Pubmed Central PMCID: 4841386. Epub 2016/01/24. eng.

31. Thandrayen K, Norris SA, Pettifor JM. Fracture rates in urban South African children of different ethnic origins: the birth to twenty cohort. Osteoporos Int. 2009;20(1):47-52 PubMed PMID: 18465189. Pubmed Central PMCID: 2859163.

32. Public Health Agency of Sweden. The childs environment for physical activity, page 21. Kalmar: Public Health Agency of Sweden; 2008. Available from: https://docplayer.se/5065-Barns-miljoer-for-fysisk-aktivitetsamhallsplanering-for-okad-fysisk-aktivitet-och-rorelsefrihet-hos-barn-ochunga.html. Accessed 30 June 2019.

33. The Swedish Consumer Agency. Regler i Sverige för lekplatser och lekredskap Sweden2013. Available from: https:/www.boverket.se/globalassets/publikationer/ dokument/2013/regler-lekredskap-kov.pdf. Accessed 19 May 2019.

34. Public Health Agency of Sweden. The childs environment for physical activity, page 17. Kalmar: Public Health Agency of Sweden; 2008. Available from: https://docplayer.se/5065-Barns-miljoer-for-fysisk-aktivitetsamhallsplanering-for-okad-fysisk-aktivitet-och-rorelsefrihet-hos-barn-ochunga.html. Accessed 30 June 2019

35. Clark EM, Ness AR, Tobias JH. Vigorous physical activity increases fracture risk in children irrespective of bone mass: a prospective study of the independent risk factors for fractures in healthy children. J Bone Miner Res. 2008:23(7):1012-22 PubMed PMID: 18570539. Pubmed Central PMCID: 2742075.

36. Fritz J, Coster ME, Nilsson JA, Rosengren BE, Dencker M, Karlsson MK. The associations of physical activity with fracture risk--a 7-year prospective controlled intervention study in 3534 children. Osteoporos Int. 2016;27(3): 915-22 PubMed PMID: 26359184

37. Statistics Sweden. Population statistics 1993 part 3, pages 166-167, 172-173 Sweden: Statistics Sweden; 1993. Available from: http://share.scb.se/OV9993/ Data/Historisk\%20statistik/SOS\%201911-/Befolkningsstatistik/Befolknings statistik\%20Del\%203\%20Folkm\%C3\%A4ngden\%20efter\%20k\%C3\%B6n\%20 \%C3\%A5lder\%20medborgarskap\%20(SOS)\%201991-2001/Befolknings statistik-1993-3-Folkmangden-kon-alder-medborgarskap.pdf. Accessed 30 June 2019.

38. Statistics Sweden. Tables of Sweden's population 2005, Pages 158-159, 164165: Statistics Sweden; 2006. Available from: http://share.scb.se/OV9993/ Data/Publikationer/statistik/_publikationer/BE0101_2005A01_BR_BE0106TAB. pdf. Accessed 30 June 2019 


\section{Publisher's Note}

Springer Nature remains neutral with regard to jurisdictional claims in published maps and institutional affiliations.

Ready to submit your research? Choose BMC and benefit from:

- fast, convenient online submission

- thorough peer review by experienced researchers in your field

- rapid publication on acceptance

- support for research data, including large and complex data types

- gold Open Access which fosters wider collaboration and increased citations

- maximum visibility for your research: over $100 \mathrm{M}$ website views per year

At BMC, research is always in progress. 